\title{
Characterization of Aiphanes aculeata fruit pulp and application in ice cream
}

\section{formulations}

\author{
Caracterização da polpa de frutas de Aiphanes aculeata e aplicação em formulações de sorvetes \\ Caracterización de la pulpa del fruto de Aiphanes aculeata y aplicación en formulaciones de helado
}

Received: 04/18/2021 | Reviewed: 04/25/2021 | Accept: 04/28/2021 | Published: 05/13/2021

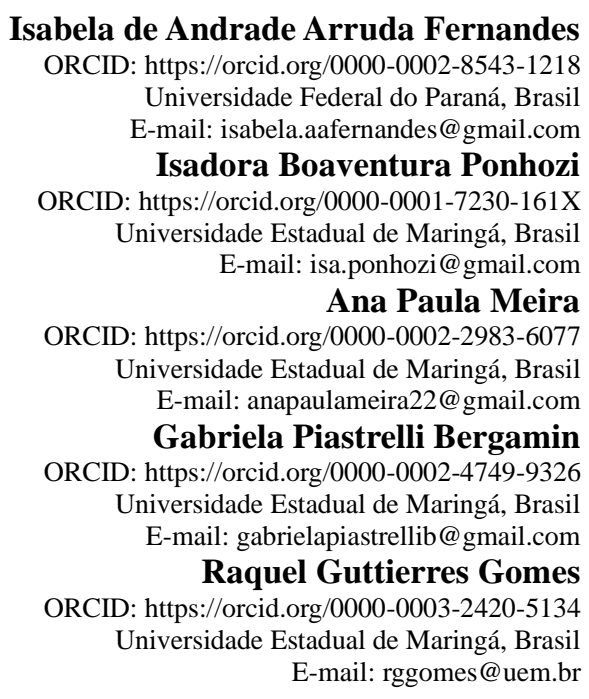

\begin{abstract}
The characteristic color of the palm fruits Aiphanes aculeata, also known as Cariota-de-Espinho, suggests the presence of pigments such as carotenoids and anthocyanins, in addition these fruits present other compounds with health benefits such as minerals, vitamins and phenolics. However, there are no studies on the application of these fruits in food formulations since this palm tree is used only for urban landscaping. The present study aimed to characterize the Aiphanes aculeata pulp for proximate composition, physicochemical parameters, mineral contents, bioactive compounds, and antioxidant activity. Three ice cream formulations with the addition of different pulp concentrations were also produced, aimed to contribute to the technological and nutritional use of Aiphanes aculeata fruits. The choice of ice cream as the main investigation occurs due to the importance of functional ice creams to the balance of the physiological functions of the human organism that occurs through the ingestion of active and nutritional ingredients. Ice creams were characterized for overrun, melting behavior, color, and texture profile. The pulp presented representative minerals levels such as iron $(49.82 \pm 43.85 \mathrm{mg} / 100 \mathrm{~g})$ and zinc $(96.07 \pm 81.65 \mathrm{mg} / 100 \mathrm{~g})$. The total carotenoids level was significant, corresponding to $92.64 \pm 0.83 \mu \mathrm{g} / 100 \mathrm{~g}$, with an emphasis on the betacarotene levels $(56.94 \pm 2.11 \mu \mathrm{g} / 100 \mathrm{~g})$. The different pulp concentrations used in the formulations influenced the characteristics of the ice cream, as it interacted positively with the ingredients until the concentration of $30 \%$ pulp. Therefore, the Aiphanes aculeata fruits showed potential for application in the food industry, in the manufacture of ice cream with high nutritional value.
\end{abstract}

Keywords: Functional foods; Carotenoids; Anthocyanins; Antioxidants; Edible ices.

\section{Resumo}

A cor característica das frutas de palmeira Aiphanes aculeata, também conhecida como Cariota-de-Espinho, sugere a presença de pigmentos como carotenoides e antocianinas, além disso esses frutos apresentam outros compostos com benefícios para a saúde como minerais, vitaminas e fenólicos. No entanto, não há estudos sobre a aplicação dessas frutas em formulações alimentares, uma vez que essa palmeira é utilizada apenas para o paisagismo urbano. O presente estudo teve como objetivo caracterizar a polpa Aiphanes aculeata em composição, parâmetros físicoquímicos, conteúdo mineral, compostos bioativos e atividade antioxidante. Também foram produzidas três formulações de sorvete com a adição de diferentes concentrações de polpa, visando contribuir para o uso tecnológico e nutricional das frutas Aiphanes aculeata. A escolha do sorvete como investigação principal se dá devido a importância de sorvetes funcionais ao equilíbrio das funções fisiológicas do organismo humano que se dá através da ingestão de ingredientes ativos e nutricionais. Os sorvetes foram caracterizados por excesso, comportamento de fusão, 
cor e perfil de textura. A polpa apresentou níveis minerais representativos como ferro $(49.82 \pm 43.85 \mathrm{mg} / 100 \mathrm{~g})$ e zinco $(96.07 \pm 81.65 \mathrm{mg} / 100 \mathrm{~g})$. O nível total de carotenoides foi significativo, correspondendo a $92.64 \pm 0.83$ $\mu \mathrm{g} / 100 \mathrm{~g}$, com destaque para os níveis de betacaroteno $(56.94 \pm 2.11 \mu \mathrm{g} / 100 \mathrm{~g})$. As diferentes concentrações de polpa utilizadas nas formulações influenciaram as características do sorvete, pois interagiu positivamente com os ingredientes até a concentração de $30 \%$ da polpa. Por isso, as frutas Aiphanes aculeata apresentaram potencial de aplicação na indústria alimentícia, na fabricação de sorvetes de alto valor nutricional.

Palavras-chave: Alimentos funcionais; Carotenoides; Antocianinas; Antioxidantes; Gelado comestíveis.

\section{Resumen}

El color característico de los frutos de la palma Aiphanes aculeata, también conocido como Cariota-de-Espinho, sugiere la presencia de pigmentos como carotenoides y antocianinas, además estos frutos presentan otros compuestos con beneficios para la salud como minerales, vitaminas y fenólicos. Sin embargo, no existen estudios sobre la aplicación de estos frutos en formulaciones alimentarias ya que esta palmera se utiliza únicamente para paisajismo urbano. El presente estudio tuvo como objetivo caracterizar la pulpa de Aiphanes aculeata en cuanto a composición próxima, parámetros fisicoquímicos, contenido mineral, compuestos bioactivos y actividad antioxidante. También se elaboraron tres formulaciones de helado con la adición de diferentes concentraciones de pulpa, destinadas a contribuir al aprovechamiento tecnológico y nutricional de los frutos de Aiphanes aculeata. La elección del helado como principal investigación se da por la importancia de los helados funcionales para el equilibrio de las funciones fisiológicas del organismo humano que se produce a través de la ingestión de principios activos y nutricionales. Los helados se caracterizaron por su comportamiento de esponjamiento, fusión, color y perfil de textura. La pulpa presentó niveles representativos de minerales como hierro $(49.82 \pm 43.85 \mathrm{mg} / 100 \mathrm{~g})$ y zinc $(96.07 \pm 81.65 \mathrm{mg} / 100 \mathrm{~g})$. El nivel de carotenoides totales fue significativo, correspondiente a $92.64 \pm 0.83 \mu \mathrm{g} / 100 \mathrm{~g}$, con énfasis en los niveles de betacaroteno $(56.94 \pm 2.11 \mu \mathrm{g} / 100 \mathrm{~g})$. Las diferentes concentraciones de pulpa empleadas en las formulaciones influyeron en las características del helado, ya que interactuó positivamente con los ingredientes hasta la concentración de $30 \%$ de pulpa. Por tanto, los frutos de Aiphanes aculeata mostraron potencial de aplicación en la industria alimentaria, en la fabricación de helados con alto valor nutricional.

Palabras clave: Alimentos funcionales; Carotenoides; Antocianinas; Antioxidantes; Helados comestibles.

\section{Introduction}

Aiphanes aculeata, popularly known as Cariota-de-Espinho or Palmeira Espinhenta, belongs to the Arecaceae family. It is a palm tree native to Latin America, found mainly in Brazil (Amazonas and Acre), Venezuela, and Bolivia, and has a characteristic feature of a stem covered with pointed spines and red fruits when ripe (Smith, 2015). The physicochemical and nutritional characteristics of the A. aculeata pulp are practically unexplored since the palm is predominantly used in urban landscaping, due to its ornamental importance (Moraes, Machado \& Araújo, 2015).

The fruits of the Aiphanes aculeata palm have a characteristic color due to their rich composition in carotenoids and anthocyanins, especially zeaxanthin, in addition to other nutrients with health benefits such as antinociceptive and antiinflammatory effect (Lakey-Beitia, Kumar, Murillo, \& Patricia, 2017). In general, palm trees are known to be rich in oils, terpenoids, and phenolic compounds (Agostini-Costa, 2018). These compounds have antioxidant potential, slowing aging and defending the body's tissues against oxidative stress and pathologies associated with inflammatory processes and cancer (Santos, Alves \& Roca, 2015), therefore with a great potential to be used as substitutes for synthetic agents in the pharmaceutical and nutraceutical industries (Maqsood et al., 2019).

In recent years, there has been an increase in studies about new functional food products using native Brazilian fruits (Schiassi et al., 2017). In this context, functional ice cream stands out, which is defined as a nutritious frozen dessert that provides high energy to consumers and is considered a complement to the diet with positive effects on human health (Öztürk, Demirci, \& Akın, 2018). More nutritious and healthy functional ice cream can be produced by the addition of fruits and constituents rich in proteins, fibers, bioactive compounds, probiotics, and prebiotics (Öztürk et al., 2018).

Therefore, the general objective of this study was to characterize the pulp of the native fruit Aiphanes aculeata (Family Arecaceae), In addition, the main objective is the development of innovative and functional products based on native fruit from Brazilian agroforestry systems, which will have its added value increased and an opportunity for sustainable 
economic use of forest resources. For this, a functional ice cream was investigated and developed in order to understand its potential and nutritional and antioxidant value for the maintenance of human health.

\section{Methodology}

\subsection{Obtaining the raw materials}

The fruit pulp of Aiphanes aculeata was collected at the State University of Maringa, located in Maringa/PR-Brazil, and stored for a maximum of $4 \mathrm{wk}$ at $6{ }^{\circ} \mathrm{C}$. For the manufacture of ice cream, the fruits were stored frozen until use and the other ingredients including milk yeast $\left(\right.$ BioRich $\left.^{\mathrm{TM}}\right)$, cream (fat contain, Frimesa ${ }^{\mathrm{TM}}$ ), stabilizer (Super liga neutra - Duas Rodas $^{\mathrm{TM}}$ ), emulsifier (Emustab Selecta - Duas Rodas ${ }^{\mathrm{TM}}$ ), and commercial sugar were purchased in the local market of Maringa/PR. The milk was purchased at the Iguatemi Experimental Farm (FEI). All analyses were performed in triplicate

\subsection{Characterization of Aiphanes aculeata fruits}

\subsubsection{Obtaining the fruit pulp}

The fruit of Aiphanes aculeata palm was washed in running water to remove visible dirt or particles, and dried using a paper towel. The pulp was removed from the fruit until obtaining a homogeneous paste by homogenizer (Britânia, BMX630PI, Joinville, Santa Catarina, Brazil).

\subsubsection{Composition}

The moisture content, total lipids, crude fiber (acid and alkaline digestion), ash, and acidity were determined according to the methods described in the analytical standards of Instituto Adolfo Lutz (2008). The protein content was determined by the total nitrogen (\%), according to the Kjeldahl method, as described by the Association of Official Analytical Chemists (AOAC) (1990). Carbohydrates were calculated by difference, by subtracting the values obtained for moisture, protein, lipids, ash, crude fiber, and protein from 100.

The $\mathrm{pH}$ values were determined by the potentiometric method. The soluble solids content was determined by reading in an Abbé refractometer at $20{ }^{\circ} \mathrm{C}$ and expressed in ${ }^{\circ} \mathrm{Bx}$. The reducing sugars (expressed as $\%$ glucose) were determined by the volumetric method using Fehling solutions (Instituto Adolfo Lutz, 2008).

\subsubsection{Color measurements}

The color of the pulp was measured using a portable colorimeter (Minolta, CR10). The results were expressed as L*, $\mathrm{a}^{*}$, and $\mathrm{b}^{*}$ values, in which $\mathrm{L}^{*}$ (luminosity or brightness) varies from black (0) to white (100), a* varies from green (-60) to red $(+60)$, and $b^{*}$ varies from blue to yellow, i.e., from -60 to +60 , respectively. The color coordinates $a^{*}$ and $b^{*}$ were $u$ sed to calculate the Hue angle $\left({ }^{\circ} \mathrm{h}=\operatorname{tang}-1\left(\mathrm{~b}^{*} / \mathrm{a}^{*}\right)\right)$, which indicates the fruit tonality (Bible \& Singha, 1993).

\subsubsection{Mineral content}

The minerals calcium, iron, magnesium, and zinc was found by atomic absorption spectrophotometer (Perkin-Elmer, 2380, Waltham, Massachusetts, USA), using a standard curve for each mineral, as proposed by Salinas \& Garcia (1985).

\subsubsection{Carotenoids content}

The extraction of carotenoids was performed as reported by Pacheco (2009). The Aiphanes aculeata pulp extracts were kept refrigerated for $24 \mathrm{~h}$. Then, the samples were weighed using an analytical balance (Bioprecisa, FA2104N, Curitiba, Paraná, Brazil). Then, $3 \mathrm{~g}$ of celite (454) was added and the carotenoids were extracted with HPLC grade acetone. The 
resulting extract was transferred to a $500 \mathrm{~mL}$ separating funnel containing about $40 \mathrm{~mL}$ of HPLC grade petroleum ether. The total carotenoids were quantified in a UV-visible spectrophotometer (Thermo Scientific, Evolution 60, Waltham, Massachusetts, USA), in the visible spectrum range, with absorbance readings at $450 \mathrm{~nm}$, using HPLC grade petroleum ether as a blank.

\subsubsection{Obtaining the anthocyanin extracts from the Aiphanes Aculeata pulp}

The anthocyanins extraction was performed according to the methodology by Teixeira, Stringheta $\&$ De Oliveira (2008) with modifications. A pulp:ethanolic solution (70\%) ratio of 1:2 was used for the extraction. The mixture was subjected to stirring on a magnetic stirrer for $40 \mathrm{~min}$ and protected from light. After extraction, the mixture was filtered and centrifuged at $4000 \mathrm{rpm}$ for $10 \mathrm{~min}$. The removal of chlorophyll from the extract was performed by extraction using $150 \mathrm{~mL}$ aliquots of ethyl ether: petroleum ether $1: 1$, for 3 times, using a separating funnel. The extract was concentrated to $30 \%$ of the initial volume in a rotary evaporator at $45{ }^{\circ} \mathrm{C}$ and protected from light, frozen in liquid nitrogen, and freeze-dried at $-50{ }^{\circ} \mathrm{C}$ for $24 \mathrm{~h}$. The freeze-dried material was stored in a freezer at $-20^{\circ} \mathrm{C}$.

\subsubsection{Total anthocyanins}

The content of total anthocyanins was determined using the differential $\mathrm{pH}$ method as described by Lee, Durst \& Wrolstad (2005). For that, two buffer systems were used, consisting of $0.025 \mathrm{M}$ potassium chloride at $\mathrm{pH} 1.0$ and $0.4 \mathrm{M}$ sodium acetate at $\mathrm{pH} 4.5$. The samples were previously filtered on Whatman $1 \varnothing$ filter paper, and absorbance readings were performed in spectrophotometer (Thermo scientific, Genesys 10S UV-Vis, Waltham, Massachusetts, USA) at $520 \mathrm{~nm}$, using distilled water as a blank.

\subsubsection{Phenolic contents and the antioxidant capacity of the extract}

The quantification of total phenolic content (TPC) of both pulp and ice creams were determined using the FolinCiocalteu colorimetric method described by Singleton \& Rossi (1965) with some modifications by Ribeiro et al. (2019). Briefly, the extract $(30 \mu \mathrm{L})$ was mixed with $2370 \mu \mathrm{L}$ of water, and then $150 \mu \mathrm{L}$ of the Folin-Ciocalteu reagent was added, and the mixture incubated in the dark for $3 \mathrm{~min}$ at $25{ }^{\circ} \mathrm{C}$. Then, $450 \mu \mathrm{L}$ of $20 \% \mathrm{Na}_{2} \mathrm{CO}_{3}$ was added and incubated for $2 \mathrm{~h}$. The absorbances were done with a spectrophotometer (Thermo scientific, Genesys 10S UV-Vis, Waltham, Massachusetts, USA) at $765 \mathrm{~nm}$.

The determination of antioxidant activity in extracts using the DPPH (2,2-diphenyl-1-picryl-hydrazil) method was based on the method of Brand-Williams, Cuvelier, \& Berset (1995), with some modifications by Ribeiro et al. (2019). Briefly, $1650 \mu \mathrm{L}$ absolute $\mathrm{C}_{2} \mathrm{H}_{5} \mathrm{OH}, 1050 \mu \mathrm{L}$ DPPH solution diluted in absolute $\mathrm{C}_{2} \mathrm{H}_{5} \mathrm{OH}(220 \mu \mathrm{mol} / \mathrm{L})$ and $300 \mu \mathrm{L}$ extract were mixed and kept in the dark for $30 \mathrm{~min}$. The absorbance was determined at $517 \mathrm{~nm}$. The FRAP assay was done using the methodology of Thaipong, Boonprakob, Crosby, Cisneros-Zevallos, \& Hawkins Byrne (2006). The FRAP reagent was prepared by mixing ethyl acetate buffer (300 mmol/L, pH 3.6), $10 \mathrm{mmol} / \mathrm{L}$ of TPTZ (diluted in $40 \mathrm{mmol} / \mathrm{L} \mathrm{HCl}$ ) and $20 \mathrm{mmol} / \mathrm{L} \mathrm{of} \mathrm{FeCl}_{3}(10: 1: 1$, v); $150 \mu \mathrm{L}$ of the extract and $2850 \mu \mathrm{L}$ of the FRAP reagent were added. The tubes were incubated for $30 \mathrm{~min}$ at $37 \pm 1^{\circ} \mathrm{C}$, and then the absorbance was determined at $594 \mathrm{~nm}$. The xanthine/luminol/xanthine oxidase system (XOD) was based on the method Hirayama et al. (1997). 


\subsection{Characteristics of Aiphanes aculeata ice cream}

\subsubsection{Manufacture of ice cream}

The following ingredients were used to produce the ice creams: fruit pulp $(15,30$, and $60 \%)$, milk $(85,60$, and $40 \%)$, sugar (18\%), cream (5\%), stabilizer (1.5\%) and emulsifier (1.5\%). A formulation without the addition of fruit pulp was used as a control. First, the pulp was mixed with milk, then homogenization with the other ingredients, the ice cream was processed in discontinuous artisanal equipment at $-18{ }^{\circ} \mathrm{C}$ for approximately $20 \mathrm{~min}$. After manufacture, the ice creams were stored protected from light at $-18{ }^{\circ} \mathrm{C}$ (Campos et al., 2016).

\subsubsection{Determination of overrun}

The air incorporation in the ice cream was determined by measuring the volume of the initial mixture $\left(\mathrm{V}_{\mathrm{i}}\right)$ and the volume of the final product $\left(\mathrm{V}_{\mathrm{f}}\right)$. The overrun was calculated by Equation 1 (Segall \& Goff, 2002):

$$
\text { overrun }=\left(\frac{V_{f}-V_{i}}{V_{i}}\right) \times 100
$$

\subsubsection{Texture profile}

The texture profile of the samples was determined four weeks after the ice cream manufacture, in triplicate, using a texture analyzer (Syable Micro System TA-XT2i) and a P/36R probe, and the results were presented in kgf compression strength.

\subsubsection{Melting behavior}

For the melting test, $100 \mathrm{~g}$ of ice cream was kept in the freezer for $60 \mathrm{~min}$. Then, the sample was placed on a metallic sieve, with sieve opening size of $0.5 \mathrm{~cm}$ at room temperature, and the drained ice cream was weighed every 10 min (Granger et al., 2005). This procedure was performed for 4 consecutive weeks from the day of manufacture, in triplicate.

\subsection{Statistical analysis}

Data were analyzed by analysis of variance (ANOVA) and Tukey's test to compare means at the level of $5 \%$ of significance. The Statistica 7.0 software (StatSoft, Tulsa, OK, USA) was used for this analysis.

\section{Results and Discussion}

\subsection{Characterization of Aiphanes aculeata fruits}

\subsubsection{Composition and physicochemical parameters}

The results of the composition and physicochemical parameters of the Aiphanes aculeata pulp are shown in Table 1 . 
Table 1. Characterization of the fruit of Aiphanes aculeata.

\begin{tabular}{lc}
\hline Characterization & Pulp \\
\hline Centesimal composition & \\
Moisture (\%) & $75.94 \pm 0.53$ \\
Ashes (\%) & $1.28 \pm 0.13$ \\
Lipids (\%) & $0.36 \pm 0.06$ \\
Protein (\%) & $7.85 \pm 0.48$ \\
Crude fiber (\%) & $1.76 \pm 0.85$ \\
Carbohydrates (\%) & $12.81 \pm 0.32$ \\
Physico-chemical parameters & \\
'Brix & \\
pH & $7.10 \pm 0.20$ \\
Reducing sugars (\%Glucose) & $4.84 \pm 0.08$ \\
Acidity (\%Citric acid) & $0.71 \pm 0.00$ \\
Water activity (Aw) & $0.43 \pm 0.04$ \\
Color & $0.96 \pm 0.00$ \\
L* & \\
a $^{*}$ & $49.60 \pm 0.24$ \\
b $^{*}$ & $29.19 \pm 0.63$ \\
h* & $58.27 \pm 0.42$ \\
\hline
\end{tabular}

Source: Author.

It is important to note in Table 1 that the calcium and magnesium levels were $37.92 \mathrm{mg} / 100 \mathrm{~g}$ and $60.67 \mathrm{mg} / 100 \mathrm{~g}$, respectively, which was lower than that obtained by Lescano et al. (2015) in macauba pulp (130 mg/100g and $123 \mathrm{mg} / 100 \mathrm{~g}$, respectively). On the other hand, the iron and zinc levels of the Aiphanes aculeata pulp were $49.82 \pm 43.85 \mathrm{mg} / 100 \mathrm{~g}$ and 96.07 $\pm 81.65 \mathrm{mg} / 100 \mathrm{~g}$, respectively, which was higher than the values found by Lescano et al. (2015) in macauba pulp, who obtained an iron level of $4.13 \pm 0.06 \mathrm{mg} / 100 \mathrm{~g}$, and zinc levels below the quantification limit, which is $3.33 \mu \mathrm{g} / \mathrm{g}$.

The pulp presented $75.94 \pm 0.53 \%$ moisture, $7.85 \pm 0.48 \%$ protein, and $12.81 \pm 0.32 \%$ carbohydrates, which was higher than those observed in fruits belonging to the same family (Arecaceae). Such as buriti pulp (Mauritia flexuosa L.) reported by Sandri et al. (2017), with values of $59.69 \pm 0.64 \%, 2.97 \pm 0.39 \%, 7.28 \%$ respectively, and macauba pulp (Acrocomia aculeata) reported by Lescano et al. (2015), with values of $48.76 \pm 1.92 \%, 5.31 \pm 0.77 \%$ and $6.92 \pm 1.26 \%$ for moisture, protein, and carbohydrates, respectively. According Sandri et al. (2017) the moisture content which can vary from 74 to $94 \%$. The values lipids $(0.36 \pm 0.06 \%)$ and crude fiber $(1.76 \pm 0.85 \%)$ levels of the Aiphanes pulp were lower than the results found by Sandri et al. (2017) in buriti pulp, with values of $20.92 \pm 0.72 \%$ and $8.56 \pm 0.15 \%$, respectively, and by Lescano et al. (2015) in macauba pulp, with values of $23.62 \pm 1.10 \%$ and $13.89 \pm 1.00 \%$, respectively. The ash content of the pulp $(1.28 \pm 0.13 \%)$ was close to that obtained for the buriti pulp $(1.04 \pm 0.04 \%)$ (Sandri et al., 2017) and macauba pulp (1.50 $\pm 0.23 \%)$ (Lescano et al., 2015).

As reported by Silva et al. (2008), there is a relationship between ${ }^{\circ} \mathrm{Bx}$ and the sugar and organic acids contents that connect to consumers preference for sweet fruits. The ${ }^{\circ} \mathrm{Bx}$ value found for the Aiphanes aculeata pulp $(7.10 \pm 0.20)$ was higher than that observed by Schiassi et al. (2017) in buriti pulp ( $\left.4.33^{\circ} \mathrm{Bx}\right)$. The $\mathrm{pH}$ value of Aiphanes aculeata pulp was $4.84 \pm 0.08$, which was higher than that reported by Sandri et al. (2017) in buriti pulp (3.78 \pm 0.04$)$ and lower than that reported by Lescano et al. (2015) in macauba pulp $(6.00 \pm 0.00)$. The low $\mathrm{pH}$ values may be due to the content of dissociable acids present in the fruit (Sganzerla, 2010), such as ascorbic, malic, tartaric, and citric acids.

The reducing sugars, in glucose, in the fruit pulp was $0.71 \pm 0.01 \%$, which was significantly lower than the content found by Sandri et al. (2017) in buriti pulp $(4.50 \pm 0.14 \%)$. 
The determination of acidity in fresh products is important to study the product conservation since this information can be related to microbial growth and fruit storage conditions (Instituto Adolfo Lutz, 2008). The titratable acidity, expressed as citric acid, in Aiphanes aculeata pulp was $0.43 \pm 0.04 \%$, which was close to that found for macauba pulp with a value of 0.27 $\pm 0.03 \%$ (Lescano et al., 2015) and significantly lower than that observed for buriti pulp, with $8.82 \pm 0.16 \%$ (Sandri et al., 2017). The water activity of the fruit pulp was 0.96 , which was close to that of buriti pulp $(0.98 \pm 0.02)$ reported by Sandri et al. (2017).

Regarding the color measurements, the pulp showed positive $\mathrm{a}^{*}$ and $\mathrm{b}^{*}$ values, corresponding to red and yellow color, respectively. These results are in accordance with the findings of Schwartz et al. (2010), who studied Butia capitata, also belonging to the Arecaceae family.

\subsection{Characterization of ice cream formulations made with the Aiphanes aculeata pulp}

\subsubsection{Overrun}

In the determination of overrun, the incorporation of air ranged from 40 to $66 \%$, as shown in Table 3 , which is in agreement with the results of Öztürk, Demirci, e Akın (2018) for ice cream made with Myrtus communis pulp, which exhibited overrun ranging from 40.95 to $42.98 \%$.

Table 3. Characteristics of ice creams with different formulations.

\begin{tabular}{|c|c|c|c|c|c|}
\hline \multirow{2}{*}{ Characteristics } & & \multicolumn{4}{|c|}{ Formulation } \\
\hline & & Control & F1 & F2 & F3 \\
\hline Overrun & $(\%)$ & $48.15 \pm 0.27^{b}$ & $55.56 \pm 1.10^{\mathrm{b}}$ & $66.18 \pm 0.94^{\mathrm{b}}$ & $39.53 \pm 0.57^{b}$ \\
\hline Color & $\begin{array}{l}\mathbf{L}^{*} \\
\mathbf{a}^{*} \\
\mathbf{b}^{*}\end{array}$ & $\begin{array}{l}83.18 \pm 0.23^{\mathrm{b}} \\
-6.84 \pm 0.02^{\mathrm{a}} \\
10.75 \pm 0.07^{\mathrm{c}}\end{array}$ & $\begin{array}{l}65.46 \pm 0.16^{\mathrm{a}} \\
4.20 \pm 0.11^{\mathrm{b}} \\
35.38 \pm 0.60^{\mathrm{a}}\end{array}$ & $\begin{array}{l}69.54 \pm 0.47^{\mathrm{a}} \\
3.88 \pm 0.38^{\mathrm{b}} \\
38.49 \pm 0.67^{\mathrm{a}}\end{array}$ & $\begin{array}{l}66.59 \pm 0.25^{\mathrm{a}} \\
7.38 \pm 0.24^{\mathrm{c}} \\
44.27 \pm 0.68^{\mathrm{b}}\end{array}$ \\
\hline Texture & $\begin{array}{l}\text { Toughness (kgf) } \\
\text { Gumminess (kgf) } \\
\text { Adhesiveness (J) } \\
\text { Chewiness (J) }\end{array}$ & $\begin{array}{l}3.39 \pm 0.26^{\mathrm{b}} \\
0.66 \pm 0.18^{\mathrm{b}} \\
0.02 \pm 0.00^{\mathrm{a}} \\
0.05 \pm 0.02^{\mathrm{b}}\end{array}$ & $\begin{array}{l}4.24 \pm 1.39^{\mathrm{b}} \\
0.88 \pm 0.33^{\mathrm{b}} \\
0.01 \pm 0.01^{\mathrm{a}} \\
0.06 \pm 0.04^{\mathrm{ab}}\end{array}$ & $\begin{array}{l}8.78 \pm 1.35^{\mathrm{a}} \\
1.93 \pm 0.31^{\mathrm{a}} \\
0.01 \pm 0.00^{\mathrm{a}} \\
0.13 \pm 0.03^{\mathrm{a}}\end{array}$ & $\begin{array}{l}2.38 \pm 0.32^{\mathrm{b}} \\
0.83 \pm 0.31^{\mathrm{b}} \\
0.02 \pm 0.01^{\mathrm{a}} \\
0.04 \pm 0.02^{\mathrm{b}}\end{array}$ \\
\hline Total Phenolics & (mgGAE/100g) & $0.00 \pm 0.00^{\mathrm{a}}$ & $2.09 \pm 0.00^{\mathrm{b}}$ & $1.06 \pm 0.01^{b}$ & $4.18 \pm 0.01^{\mathrm{c}}$ \\
\hline
\end{tabular}

Legend: Mean \pm standard deviation. Means followed by the same letter, in the same column, do not differ by Tukey's test ( $\mathrm{p}<0.05)$. F1: 15\% pulp, F2: $30 \%$ pulp and F3: $60 \%$ pulp.

Source: Author.

The formulation with the addition of $30 \%$ Aiphanes aculeata pulp showed the highest overrun, probably due to its composition, giving the product a greater creaminess, and consequently higher yield. The incorporation of air into the ice cream depends on the total solids content, and in general, there is an increase in overrun with the increase in total solids, improving the ice cream characteristics such as the texture. However, Goff and Hartel (2013) reported that total solids content above $42 \%$ can lead to very dense products and, consequently, with lower incorporation of air. This event may have occurred in formulation 3, which contained a higher pulp concentration, and higher total solids and fiber contents, resulting in a product with lower incorporation of air. The results corroborate the findings of the characterization of Aiphanes aculeata fruits, which presented $1.76 \%$ crude fiber, contributing to higher fiber content in the formulations made with the higher pulp concentration, thus requiring more force during beating to increase the incorporation of air in the ice cream. 
As can be seen in Table 3, the $\mathrm{b}^{*}$ values increased with increasing the pulp concentration. This result may be due to the addition of pulp and other components to the ice cream mixture to increase the functionality and improve the sensory properties, leading to a reduction of $\mathrm{L}^{*}$ values and an increase in $\mathrm{b}^{*}$ values of ice cream (Öztürk et al., 2018).

\subsubsection{Texture profile}

Table 3 shows the results of the texture profile analysis of the ice cream formulations. Dervisoglu \& Yazici (2006) studied the effect of the addition of citrus fibers to ice cream and reported that the fiber reduced overrun, as it increased the product's viscosity. This behavior was also observed in F3 (60\%), which contained the highest pulp concentration and presented a lower hardness and higher adhesiveness. The formulation 2 showed greater overrun and hardness when compared to other formulations, due to the greater volume of the frozen mixture. In addition, F2 showed greater gumminess and chewability, requiring a greater strength to break down and chew the ice cream, respectively (Silva et al., 2013). No significant differences were observed for the adhesiveness of the samples, that is, they presented similar efforts to break the attraction forces between the product and the contact surface (Goff \& Hartel, 2013).

\subsubsection{Melting behavior}

The melting test was performed for 4 weeks, as shown in Figure 1. It is important to note in Figure 1 that the formulation F3 presented a more discrepant behavior, starting the melting process after the other samples, probably due to lower incorporation of air and a higher pulp concentration, conferring a great firmness to the product. As reported by Correia et al. (2008), high total solids levels and low overrun may be associated with slower melting.

An ideal melting behavior is characterized by a sequence of events, with the product becoming a smooth and homogeneous fluid (Goff \& Hartel, 2013). Therefore, the formulation F1 (15\%) showed a behavior closer to the ideal, with more homogeneous melting and a curve closer to the control. 
Figure 1. Analysis of melting of Aiphanes aculeata functional ice cream. (A) first week, (B) second week, (C) third week and (D) fourth week. F1: 15\% pulp, F2: 30\% pulp and F3: 60\% pulp.
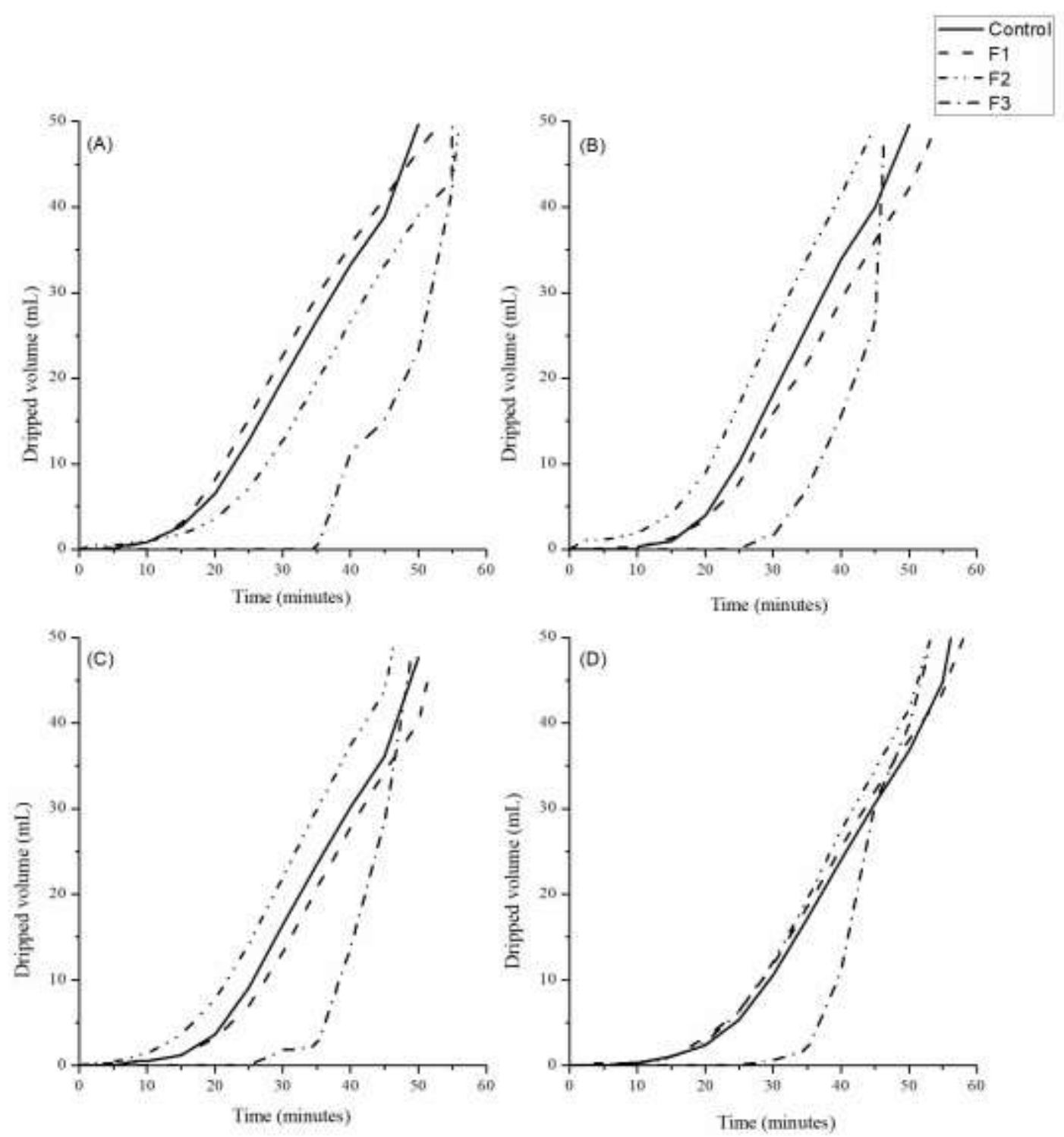

Source: Authors.

The ice cream made with the highest pulp concentration $(60 \%)$ showed a lower overrun and slower melting, in addition to a more fibrous and dense aspect when compared to the others. This result may be due to the high molecular weight, leading to a firmer agglomerate and higher product viscosity (Silva Junior \& Lannes, 2011). In addition, other factors can affect the process including the rate of air incorporation (overrun), lipid interactions, and fat crystallization (Sofjan \& Hartel, 2004). The addition of 15 and $30 \%$ pulp to the ice cream formulations provided a melting behavior close to the control, with an expected melting resistance and good creaminess. It is worth noting that ice creams with the addition of Aiphanes aculeata pulp had higher total phenolic compounds (Table 3) with functional properties when compared to traditional ice creams.

\section{Conclusion}

The Aiphanes aculeata fruit pulp exhibited behavior similar to the fruits from the same species or family, which have already been used in the food industry. For the manufacture of functional ice cream, the pulp showed adequate interaction with the ingredients up to a concentration of $30 \%$, with high levels of total phenolic compounds and good performance of the 
characteristics studied, with positive effects on overrun, melting behavior, and texture profile. Therefore, the fruit can be an alternative source for the manufacture of food products with high nutritional value, some of which have the functional potential to benefit human health. A diet rich in phenolic compounds is linked to a decreased risk of multiple diseases, so consumers increasingly want to consume natural ice cream with enhanced bioactivity, that is, with more active ingredients such as phenolics and antioxidant activity. For future work, investigate toxicity and perform sensory analysis and thus apply the pulp in the development of other foods.

\section{Conflict of Interest}

The authors declare no conflict of interest.

\section{References}

Agostini-Costa, T. S. (2018). Bioactive compounds and health bene fi ts of some palm species traditionally used in Africa and the Americas - A review. In Journal of Ethnopharmacology. https://doi.org/10.1016/j.jep.2018.05.035

Akalın, A. S., Kesenkas, H., Dinkci, N., Unal, G., Ozer, E., \& Kınık, O. (2018). Enrichment of probiotic ice cream with different dietary fibers: Structural characteristics and culture viability. Journal of Dairy Science, 101(1), 37-46. https://doi.org/10.3168/jds.2017-13468

Association of Official Analytical Chemists. (1990). Official Methods of Analysis (15th ed.), K. Helrich, Ed. Arlington: Association of Official Analytical Chemists.

Bible, B. B., \& Singha, S. (1993). Canopy position influences CIELAB coordinates of peach color. HortScience, 28(10), 992-993. https://doi.org/10.21273/hortsci.28.10.992

Brand-Williams, W., Cuvelier, M. E., \& Berset, C. (1995). Use of a free radical method to evaluate antioxidant activity. LWT-Food Science and Technology, $28,25-30$.

Campos, B. E., Dias Ruivo, T., da Silva Scapim, M. R., Madrona, G. S., \& de C. Bergamasco, R. (2016). Optimization of the mucilage extraction process from chia seeds and application in ice cream as a stabilizer and emulsifier. LWT - Food Science and Technology, 65, 874-883. https://doi.org/10.1016/j.lwt.2015.09.021

Correia, R. T. P., Dos Anjos Magalhães, M. M., Da Silva Pedrini, M. R., Da Cruz, A. V. F., \& Clementino, I. (2008). Sorvetes elaborados com leite caprino e bovino: Composição química e propriedades de derretimento. Revista Ciencia Agronomica, 39(2), 251-256.

Dervisoglu, M., \& Yazici, F. (2006). Note. The effect of citrus fibre on the physical, chemical and sensory properties of ice cream. Food Science and Technology International, 12(2), 159-164. https://doi.org/10.1177/1082013206064005

Goff, H. D., \& Hartel, R. W. (2013). Ice Cream. In Ice Cream (7th ed.). https://doi.org/10.1007/978-1-4615-0163-3_5

Granger, C., Leger, A., Barey, P., Langendorff, V., \& Cansell, M. (2005). Influence of formulation on the structural networks in ice cream. International Dairy Journal, 15(3), 255-262. https://doi.org/10.1016/j.idairyj.2004.07.009

Hirayama, O., Takagi, M., Hukumoto, K., \& Katoh, S. (1997). Evaluation of antioxidant activity by chemiluminescence. Analytical Biochemistry, 247(2), 237-241. https://doi.org/10.1006/abio.1997.2053

Instituto Adolfo Lutz. (2008). Métodos Físico-Químicos para Análise de Alimentos. Instituto Adolfo Lutz.

Lakey-Beitia, J., Kumar, D. J., Murillo, E., \& Patricia, L. (2017). Anti-amyloid aggregation activity of novel carotenoids : implications for Alzheimer' s drug discovery. Clinical Interventions in Aging, 12, 815-822.

Lee, J., Durst, R. W., \& Wrolstad, R. E. (2005). Determination of total monomeric anthocyanin pigment content of fruit juices, beverages, natural colorants, and wines by the $\mathrm{pH}$ differential method: Collaborative study. Journal of AOAC International, 88(5), 1269-1278. https://doi.org/10.1093/jaoac/88.5.1269

Lescano, C. H., Oliveira, I. P. De, Silva, L. R., Baldivia, D. S., Sanjinez-Argandoña, E. J., Arruda, E. J., \& Lima, F. F. (2015). Nutrients content , characterization and oil extraction from Acrocomia aculeata ( Jacq .) Lodd . fruits. African Journal of Food Science, 9(3), 113-119. https://doi.org/10.5897/AJFS2014.1212

Maqsood, S., Adiamo, O., Ahmad, M., \& Mudgil, P. (2019). Bioactive compounds from date fruit and seed as potential nutraceutical and functional food ingredients. Food Chemistry, 308, 125522. https://doi.org/10.1016/j.foodchem.2019.125522

Moraes, L. A., Machado, R. R. B., \& Araújo, M. F. V. (2015). O babaçu na zona urbana de Teresina - PI: distribuição e viabilidade paisagística. Revista Equador, 4(4), 112-133.

Öztürk, H. İ., Demirci, T., \& Akın, N. (2018). Production of functional probiotic ice creams with white and dark blue fruits of Myrtus communis: The comparison of the prebiotic potentials on Lactobacillus casei 431 and functional characteristics. LWT - Food Science and Technology, 90(November 2017), 339-345. https://doi.org/10.1016/j.lwt.2017.12.049 
Pacheco, S. (2009). Preparo de padrões analíticos, estudo de estabilidade e parâmetros de validação para ensaio de carotenóides por cromatografia líquida (Universidade Deferal Rural do Rio de Janeiro). Retrieved from https://tede.ufrrj.br/jspui/handle/tede/414

Pascual, C., Gonzalez, R., \& Torricella, R. G. (1994). Scavenging action of propolis extract against oxygen radicals. Journal of Ethnopharmacology, 41(1-2), 9-13. https://doi.org/10.1016/0378-8741(94)90052-3

Ribeiro, V. R., Maciel, G. M., Fachi, M. M., Pontarolo, R., Fernandes, I. de A. A., Stafussa, A. P., \& Haminiuk, C. W. I. (2019). Improvement of phenolic compound bioaccessibility from yerba mate (Ilex paraguariensis) extracts after biosorption on Saccharomyces cerevisiae. Food Research International, 126(April), 108623. https://doi.org/10.1016/j.foodres.2019.108623

Salinas, J. G., \& Garcia, R. (1985). Metodos quimicos para el analisis de suelos acidos y plantas forrajeras. Cali: Centro Internacional de Agricultura Tropical (CIAT).

Sandri, D. D. E. O., Luiza, A., Pereira, R., Rodrigues, E. C., Morais, E. C. D. E., \& Barros, W. M. D. E. (2017). Antioxidant activity and phusicochemical characteristics of Buriti pulp (Mauritia flexuosa) collected in the city of Diamantino- MTS. Revista Brasileira de Fruticultura, 39(3), 864-871. https://doi.org/10.1590/0100-29452017

Santos, M. F. G., Alves, R. E., \& Roca, M. (2015). Carotenoid composition in oils obtained from palm fruits from the Brazilian Amazon. Grasas y Aceites, 66(3), 86-93. https://doi.org/10.3989/gya.1062142

Schiassi, M. C. E. V, de Souza, V. R., Lago, A. M. T., Campos, L. G., \& Queiroz, F. (2017). Fruits From The Brazilian Cerrado Region: Physico-Chemical Characterization, Bioactive Compounds, Antioxidant Activities, And Sensory Evaluation. Food Chemistry, 245 , 305-311. https://doi.org/10.1016/j.foodchem.2017.10.104

Schwartz, E., Fachinello, J. C., Barbieri, R. L., \& Silva, J. P. (2010). Avaliação de populações de Butia capitata de Santa Vitória do Palmar. Revista Brasileira de Fruticultura, 32(3), 736-745.

Segall, K. I., \& Goff, H. D. (2002). A modified ice cream processing routine that promotes fat destabilization in the absence of added emulsifier. International Dairy Journal, 12(12), 1013-1018. https://doi.org/10.1016/S0958-6946(02)00117-6

Sganzerla, M. (2010). Caracterização físico-química e capacidade antioxidante do butiá (Universidade Federal de Pelotas). http://www.dominiopublico.gov.br/download/texto/cp128297.pdf

Silva, A. C. da, Pires, A. C. dos S., Marcondes, M. I., \& Silva, M. F. da. (2013). Influence of milk type in texture and stability of ice cream. Revista Do Instituto de Laticínios Cândido Tostes, 68(393), 26-35. https://doi.org/10.5935/2238-6416.20130032

Silva Junior, E., \& Lannes, S. C. S. (2011). Effect of different sweetener blends and fat types on ice cream properties. Ciencia e Tecnologia de Alimentos, 31(1), 217-220. https://doi.org/10.1590/S0101-20612011000100033

Singleton, V. L., \& Rossi, J. A. (1965). Colorimetry of Total Phenolics with Phosphomolybdic-Phosphotungstic Acid Reagents. American Journal of Enology and Viticulture, 16(3), 144 LP - 158. Retrieved from http://www.ajevonline.org/content/16/3/144.abstract

Smith, N. (2015). Palms and People in the Amazon. Springer International Publishing.

Sofjan, R. P., \& Hartel, R. W. (2004). Effects of overrun on structural and physical characteristics of ice cream. International Dairy Journal, 14(3), 255-262. https://doi.org/10.1016/j.idairyj.2003.08.005

Teixeira, L. N., Stringheta, P. C., \& de Oliveira, F. A. (2008). Comparação de métodos para quantificação de antocianinas. Revista Ceres, 55(4), $297-304$.

Thaipong, K., Boonprakob, U., Crosby, K., Cisneros-Zevallos, L., \& Hawkins Byrne, D. (2006). Comparison of ABTS, DPPH, FRAP, and ORAC assays for estimating antioxidant activity from guava fruit extracts. Journal of Food Composition and Analysis, 19(6-7), 669-675. https://doi.org/10.1016/j.jfca.2006.01.003 